\title{
Lessons From Rojava for the Paradigm of Social Ecology
}

\author{
Cihad Hammy ${ }^{1}$ and Thomas Jeffrey Miley ${ }^{2 *}$ \\ ${ }^{1}$ Independent Researcher, Hamburg, Germany, ${ }^{2}$ Department of Sociology, Faculty of Human, Social and Political Science, \\ School of the Humanities and Social Sciences, University of Cambridge, Cambridge, United Kingdom
}

\section{OPEN ACCESS}

Edited by:

Lorenzo Posocco,

University College Dublin, Ireland

Reviewed by:

Yasin Sunca,

Bielefeld University, Germany larfhlaith Watson,

University College Dublin, Ireland

${ }^{*}$ Correspondence:

Thomas Jeffrey Miley

thomas.j.miley@gmail.com

Specialty section: This article was submitted to

Comparative Governance, a section of the journal

Frontiers in Political Science

Received: 15 November 2021 Accepted: 20 December 2021

Published: 10 January 2022

Citation:

Hammy C and Miley TJ (2022) Lessons From Rojava for the Paradigm of

Social Ecology.

Front. Polit. Sci. 3:815338. doi: 10.3389/fpos.2021.815338
This essay addresses two related questions raised by the editors of the research topic for "Beyond the Frontiers of Political Science: Is Good Governance Possible in Cataclysmic Times?" In particular, it explores: 1) how we can identify new tools and perspectives from which to address the multiple and mutually reinforcing problems accumulating around climate change; and 2) what institutional alternatives to the nation-state need to be created and empowered to tackle such complex problems. It does so through an in-depth treatment of the paradigm of "social ecology" and the associated political project of "democratic confederalism." It begins with an overview of the argument, first advanced by Murray Bookchin and subsequently adopted and adapted by the imprisoned Kurdish leader Abdullah Öcalan, that building an ecological society requires an assault on hierarchy in all its forms, and the construction of alternative, direct-democratic institutions capable of transcending the system of the capitalist nation-state. It sketches the institutional architecture of popular assemblies central to this project, both emphasizing their potential to contest capitalist social-property relations and hierarchies intrinsic to the nation-state and pointing out some sources of resilience of the existing system. It hones in on the experience of the revolutionary forces in control of the Autonomous Administration of North East Syria (AANES), who have been directly inspired by Öcalan's ideas. It highlights both the AANES's achievements as well as the significant obstacles it has encountered in the attempt to bring into being a radically-egalitarian, ecological society. It concludes by drawing lessons from these difficulties.

Keywords: social ecology, democratic confederalism, Kurdish movement, Rojava, Murray Bookchin, Abdullah Ocalan

\section{INTRODUCTION}

Murray Bookchin first advanced the proposition that the very notion of the domination of humans over nature was rooted in the domination of humans over humans in his 1964 essay, "Ecology and Revolutionary Thought" (Hammy, 2021, p.31). It followed, for Bookchin, that building an ecological society would require an assault on hierarchy in all its forms, and an embrace of a radical, directdemocratic alternative, one capable of confronting and ultimately overcoming the domination and exploitation embodied in the system of the capitalist nation-state. To this end, he would subsequently elaborate a program of communalism, which was conceived to include the concrete political dimension of libertarian municipalism. The paradigm of social ecology, linking the fate of ecological society to that of a revolutionary political project of local direct democracy, operating against and tending towards the transcendence of both capitalism and the nation-state, was thus born. 
Decades later, from his lonely prison cell on Imrali island, the leader of the Kurdish Freedom Movement, Abdullah Öcalan, would come across the work of Bookchin and would be duly impressed with what he read. Öcalan would creatively appropriate and incorporate much of the paradigm of social ecology into his own impressive re-articulation of the principle of self-determination, his tactical and strategic reorientation of the movement's aims, away from the pursuit of a Greater Kurdish nation-state, centering instead the struggle for direct democracy against the state, alongside the struggle for ecological sustainability, and the struggle for gender emancipation, as the three main pillars upon which the movement's new program of democratic confederalism is founded (Akkaya and Jongerden, 2012; Gerber and Brincat, 2021; Guneser, 2021).

This paper will explore the social-ecological dimension of the democratic confederal project, in theory and in praxis, with a focus on the challenge that the project presents to both capitalism and the nation-state system. It will begin with a summary overview of the argument, originally advanced by Bookchin and subsequently taken up by Öcalan, that would diagnose hierarchy and domination among humans as the root cause of our ecological crisis. It will then turn to sketch the alternative institutional architecture of local, direct-democratic assemblies, as envisioned and prefigured in the project. It will emphasize how such assemblies have the potential to contest capitalist social-property relations as well as hierarchies intrinsic to the nation-state form, but it will also address some sources of resilience of capitalist and nation-statist hierarchies in response to this democratic-confederalist challenge. To this end, it will hone in on the experience of the revolutionary forces in control of the Autonomous Administration of North Eastern Syria (AANES), who have been directly inspired by the democratic-confederal program as articulated by Öcalan. It will provide a critical assessment of both the AANES's main achievements, as well as the significant obstacles that the AANES has encountered in the attempt to bring into being a radically-egalitarian, ecological society. The paper will conclude by drawing some lessons from the difficulties faced by the AANES in its efforts to construct an anti-hierarchical, ecological alternative to capitalism and to the nation-state, from the bottom up.

Our careful treatment of the democratic-confederal alternative to capitalist modernity, as well as the lessons we draw from the revolutionary praxis in Rojava, are directly relevant to addressing the question: Is good governance possible in cataclysmic times? For if capitalism and the nation-state can plausibly be portrayed as culpable systemic causes of the unfolding climate catastrophe, then prospective alternatives to capitalism and the nation-state certainly deserve our very close and critical attention. Amidst a spiraling, negative dialectic of tyranny and chaos engulfing the so-called Middle East, at the very epicenter of geopolitical machinations and neoImperialist conflict, there stands out, as a beacon of hope, the revolutionary experiment underway in Rojava. A critical assessment of its achievements and failures, in relation to the paradigm of social ecology and the program of democratic confederalism, is perhaps long overdue.
The paper is written from a perspective of critical solidarity with the Kurdish Freedom Movement. It is based on a secondary analysis and synthetic assessment of existing social scientific research, but informed by primary analysis from an ongoing engagement with the movement, as well as from some twenty semi-structured interviews conducted with people associated with the movement in Rojava, from the Spring of 2018 and the Fall of 2021. With the movement, the authors share the commitment to the paradigm of social ecology and the program of democratic confederalism. In this respect, our criticisms of both the theory and the praxis of the Rojava revolution differ fundamentally from the assessment advanced by Michiel Leezenberg (2016), with whom we nevertheless converge on some important points. However, Leezenberg's critique ignores two crucial tendencies within the movement to which our analysis is quite sensitive. First, we would highlight Öcalan's emphasis on self-criticism within the movement, an emphasis on the need for a constant struggle, through education and consciousness-raising, which dates back to the 1980's, but which was intensified after the dissolution of the Soviet Union and has constituted a continuing theme in Öcalan's writings, especially since his imprisonment. Öcalan has made a consistent effort to push the Kurdistan Workers' Party (PKK) toward an ever-more radical-democratic stance, to embrace gender equality and people empowerment, by moving beyond the nation-state, nationalism, patriarchy, and authoritarianism within the PKK (e.g., Öcalan, 2011a). Second, we would highlight the corresponding widespread practice of self-criticism within the movement and amongst its supporters, which manifests itself in daily discussions among the cadres themselves, regarding mistakes, obstacles, creeping authoritarianism, and what the correct implementation of democratic confederalism in praxis requires. Likewise, the supporters of the movement, Apocis, who are inspired by Öcalan's writings, have cultivated the custom of expressing their misgivings and criticisms about what really exists. In our view, this self-critical praxis is essential for the movement's vitality, and constitutes a necessary safeguard against the degeneration of theoretical inspiration and revolutionary imagination into rigid, dogmatic mentalities. Our intention is therefore closer to that of Azize Aslan, who ends her in many ways impressive recent investigation into the anti-capitalist economy and contradictions in Rojava with a call for the movement to "continue creating a self-critical revolution" (Aslan, 2021, p. 333).

Indeed, we believe that one of the real strengths of the Kurdish movement is its refusal to be trapped in what it is. The Kurdish movement has always accepted contradiction, in the Hegelian way, in which identity negates itself. This means that the movement has always tried to transcend itself; it has always tried to transcend its own identity. This process has shown itself in the form of self-criticism in the daily practice of the PKK and in the writings of Öcalan. Inspired by this transcendence of identity, our paper aims to express our critique of the identity of the Rojava Revolution (what it is) as opposed to what it ought be (free and democratic society). Through constructive criticism, we try to promote openness instead of dogmatism and rigidity. 


\section{THE PARADIGM OF SOCIAL ECOLOGY AND THE PROJECT OF DEMOCRATIC CONFEDERALISM}

In The Ecology of Freedom, Bookchin would famously contend that "nearly every ecological issue is also a social issue," and that, in fact, "our present-day ecological dislocations have their basic sources in social dislocations" (Bookchin, 2005, p.32). Bookchin would go on to elaborate a relatively sophisticated, though albeit admittedly speculative, metanarrative about the emergence of hierarchy and domination, tracing their origins in order to denaturalize them. According to him, the emergence of hierarchy and domination both precedes and facilitates the foundation of the state and the division of the social order into economic classes. As Fischer has aptly summarized, for Bookchin, "the modern state is the manifestation of hierarchy, which together with capitalism is the source of the contemporary ecological crisis" (2017, p. 238). Furthermore, Bookchin would insist, since, for it to be effective, the struggle against climate catastrophe must entail a struggle against its root causes, this means that such a struggle must attempt simultaneously to transcend both the state and capitalism.

More recently, Öcalan has articulated a very similar line of argument. In his five-volume Manifesto for a Democratic Civilization, whose third volume is tellingly titled, in a nod to Bookchin, The Sociology of Freedom (2020), Öcalan, too, provides his own rather ambitious sketch of the emergence of hierarchy and domination, and their subsequent development over the course of a 5,000 years history. Like Bookchin, Öcalan argues that "when man began to enslave his brother, he also began to enslave nature" (quoted in Hammy, 2021, p.32). So too, like Bookchin, does Öcalan contend that the rise of hierarchy and domination precedes and paves the way for the emergence of the state and the division of the social order into economic classes. But whereas Bookchin would locate gerontocracy as the first hierarchical form to emerge, for Öcalan the original emergent hierarchical form is alleged to be that of patriarchy. Even so, Öcalan nevertheless concurs with Bookchin that the state and capitalism are quintessentially and intrinsically-interrelated hierarchical systems, both of which must be simultaneously confronted and ultimately overcome for the realization of selfdetermination and, concomitantly, for the achievement of ecological sustainability.

Likewise, both Bookchin and Öcalan posit a dialectic of domination and resistance, thread like a double-helix across history. They both believe that domination inevitably breeds resistance, and that, indeed, such resistance need not be rendered futile. Accordingly, they elaborate a program and strategy for effectively unravelling hierarchy, among other things, by espousing a prefigurative politics that they think will prove capable of consistently contesting both the state and capitalism. This is the program that Bookchin came to label "libertarian municipalism," and that Öcalan, in turn, prefers to call "democratic confederalism."

It would, of course, be a mistake, to assimilate Öcalan's thought to that of Bookchin, or even to exaggerate Bookchin's formative influence upon Öcalan's "paradigm shift." For indeed, as Cihad Hammy has elsewhere insisted, the emergence of ecological consciousness and even the anti-statist turn in Öcalan's thought can be traced back to the early 1990's, well before his encounter with Bookchin's works (2021). What's more, before reading Bookchin's The Ecology of Freedom, Öcalan had already articulated, in his book, The Roots of Civilization, a dialectic of resistance and domination in reading history which is in some ways strikingly similar to Bookchin's legacy of freedom and domination (2007). However, in that book, Öcalan deeply examined the legacy of freedom in the Middle East region, with a particular emphasis on the legacy of libertarian traditions in Islam. Recognition of the existence of such a legacy is completely absent from Bookchin's unabashedly Eurocentric account of the "universal" legacy of freedom.

More specifically, Öcalan has gone to great lengths to unearth and revive libertarian and communal traditions in the Middle East in general and in Kurdistan in particular, in order to pave the way for the possibility of applying "democratic confederalism" in the region. These efforts have been concretized in the last two volumes of his five-volume Manifesto for a Democratic Civilization, entitled The Civilizational Crisis in the Middle East and the Democratic Civilization Solution (2016b) and The Manifesto of the Kurdistan Revolution (2017), respectively. In these volumes, Öcalan defines the history of civilization in the Middle East as the history of counterrevolution, a counterrevolution against all those who are excluded from the civilizational system. It is a counterrevolution against women, the youth, the agrarian and village society, the tribes, the nomads, Sufism, the Batiniyya and other religious minorities in the region (Öcalan, 2016b, p.75). Against this counterrevolution, Öcalan aims to revive, and democratize, the legacy of resistance and rebellion of the "elements of democratic civilization," in a democratic confederalist model, opposed to the model of the nation-state, since the nation-state seeks to assimilate and eradicate the ethnic and religious diversity of the region.

Despite this important difference in emphasis, there nevertheless remains a clear, even uncanny, convergence between Bookchin and Öcalan, both with respect to the scope and content of their overarching metanarratives about the dialectic of domination and resistance, unfolding across thousands of years of history, as well as about the political program or approach of "libertarian municipalism" or "democratic confederalism" which the two thinkers similarly elaborate and embrace.

The core institutional embodiment of this approach is the call for the construction of direct-democratic, citizens' assemblies, to be "organized around neighborhoods, villages, and towns" (Fischer, 2017, p.240). Bookchin advocated such popular assemblies as sites for cultivating, indeed, resuscitating, the long-lost arts of democratic debate and collective decisionmaking (1992, p.249-251). The promotion of participation in these popular assemblies, he hoped, could help trigger the transformation of people's consciousness, facilitating their conversion from passive spectators into active citizens. Öcalan, too, puts a lot of faith in the potential for popular assemblies to help bring about nothing short of a revolution in consciousness. Moreover, he advocates the organization and coordination of 
such popular assemblies across multiple scales-envisioning a "dynamic democratic process that extends from local communities in villages and towns, through city councils and city administrations, to a general people's congress" (2010, p.462; see also Knapp and Jongerden, 2014, p.92).

Likewise, Bookchin foresaw a scenario in which a myriad of local-level popular assemblies could flourish and proliferate, and even come to be knit together in a confederation sufficient in scope to constitute an effective "dual power," one that could pose a serious challenge to the authority and jurisdiction of the state. When that time arrives, he warned, there is bound to surface a serious conflict with the state. A moment of truth, if you will, in which the direct-democratic movement will either be radicalized and rise to the challenge, resolutely facing the consequences of that conflict, including the imperative of organizing for selfdefense, or, alternatively, it will come to be compromised and ultimately re-absorbed back into the decadent but still hegemonic social order out of which it had emerged (2015a, p.18).

Öcalan, even moreso, has emphasized the importance of organizing for self-defense. Indeed, he has argued, in no uncertain terms, that " $[\mathrm{i}] \mathrm{t}$ is imperative that self-defense be established and always be at the ready to defend democratic society" (2020, p.191). To this end, he has built into his articulation of "democratic confederalism" the call for the construction, alongside the popular assemblies, of popular militias, autonomous but coordinated for the purpose of selfdefense. His is an openly spartan model of an armed citizenry, or better yet, of a revolutionary people in arms (see also Üstündag, 2016, p.199-200). Importantly, while elaborating the imperative of self-defense, Öcalan warns against "falling into either of two mistakes"-the first, of "entrusting self-defense to the monopolistic order"; the second, "try[ing] to become a power apparatus under the rubric of forming a state to counter the existing state" (2020, p.191).

The challenge this model poses to the state, with its bureaucratic hierarchies and its characteristic claim to a monopoly of legitimate violence, should thus come across as relatively evident, at least on first blush. But what about the challenge this model of social organization poses to capitalist social-property relations? Perhaps this is less evident. Yet a challenge is present, nevertheless. For the local assemblies are envisioned as empowered to oversee the means of production, to render economic motives subordinate to the will of the people, as formed and expressed in the deliberations and decisions of the assemblies. According to this model, economic forces are not to be "nationalized"; rather, they are to be "municipalized," that is, democratized, put at the service of the communities in which they are located. In Bookchin's words: "In a libertarian municipalist society, the assembly would decide the policies of the entire economy. Workers would shed their unique vocational identity and interests, at least as far as the public realm is concerned, and see themselves as citizens in their community. The municipality, through the assembly of its citizens, would control and make the broad decisions for its shops, lay down the policies that they should follow, always working with a civic outlook rather than an occupational one" (in Biehl, 1998, p.161-162).
For his part, Öcalan has conceptualized the economic plank of his democratic confederal project in terms of "economic autonomy" and "communal economy." He argues, in relation to the goal of self-determination, that democratic confederalism implies "reestablishing control over ... [the] economy." Economic autonomy, he claims, is "predicated neither on private capitalism nor on state capitalism." Instead, he insists, it is all about democratizing the economy, as well as rendering it compatible with "ecological society." "In economic autonomy," he contends, "there is no room for industry, development, technology, ownership, or rural-urban settlement, that negate ecological and democratic society." And, indeed, he adds, in this model "profit and capital accumulation is minimalized," even if, at the same time, he seeks to reassure, economic autonomy does not reject outright "the market, trade, product variety, competition, and productivity" (2016a, p.47-48; see also Aslan, 2021, p.207-208).

The "municipalized economy," or the "communal economy" and "economic autonomy," can and should be distinguished from the state-socialist objective of nationalization, on the one hand, as well as from workerist alternatives based on the democratization of social relations which focus primarily on the point of production, on the other. Not that either Bookchin or Öcalan objects in principle to workers' councils and cooperative ventures; to the contrary, both have lent explicit support to such efforts to democratize the point of production. Öcalan, for instance, has openly called for the establishment of "communal cooperatives in farming, but also in the water economy and the energy sector" (2011b, p.38). But the point, for both Bookchin and Öcalan, is that all market forces, cooperatized or not, must ultimately be subordinated to the democratic will of the citizenry as formed and expressed in the communes, or popular assemblies. For, as Bookchin has warned, absent a more all-encompassing, territorial basis for the exercise of direct democracy, so-called workerist alternatives can be all too easily incorporated into a competitive, corporate-capitalist modus operandi. This is why, in the last instance, both Bookchin and Öcalan promote and espouse a territorial basis, rather than a productive basis, for selfdetermination, that is, for the exercise of democratic control.

This model, admittedly, raises many questions about the extent to which it actually implies the transcendence of capitalist social-property relations, as opposed to a mere taming of market excesses. It is, in this vein, certainly indicative that the model does not include the abolition of private property per se. The public/private dichotomy thus remains, in principle, intact. And consequently, the division of the social order into economic classes, which, in turn, brings us back to the question of the role of the state.

Öcalan defines the state as "the unity of power relations through which the general coercion and exploitation of classed society is enabled" (Öcalan, 2015, p. 158). He, furthermore, insists that " $[t]$ he state organization is, at its heart, the collective means of protection of. . . stolen property ..." (Öcalan, 2015, p. 172). If, following Öcalan, among others, we thus conceive of the state as a set of institutions, one of whose principal purposes is to preserve existing social-property relations, then we should expect the propertied classes to appeal to it in order to fend off any 
fundamental threat to their property, should such a threat be posed by the popular assemblies. This is why, as Fischer has pointed out, "in the interest of being able to challenge the power of the state, as well as protecting themselves from state incursions, there would have to be a larger confederal association of communes that enables the construction of workable alternative organizational structures," and that could thus provide "the basis for an oppositional stance against the central authorities" (2017, p.241). But does this not mean, essentially, that to protect itself from the state, the movement would be forced to build its own state of sorts?

Bookchin relies upon a distinction between policy-making and policy implementation in order to defend the idea that the confederal association of communes is fundamentally different in nature from the state (2015b, p.40; see also Fischer, 2017, p.241). According to him, policy-making is to be confined to the realm of the communes themselves, from the bottom up, as it were, whereas the confederal association's role is intended to be limited to policy implementation alone. However, this distinction is ultimately difficult to sustain. What happens if the policies made by different communes directly contradict and come up against one another?

In such instances, and more generally, the neutrality of the administrator turns out to be an impossibility. The administrator upon whom the task of policy implementation is delegated inevitably assumes a policy-making role. Nor is this tendency towards creeping centralization only the case in the legislative domain. It is arguably even more pronounced in the domain of coercive force, where confederal associations intended to coordinate and render effective the organization of self-defense end up in the possession of concentrated power, rendering them in quintessence indistinguishable from the coercive apparatus of the state.

Let us label these twin dangers of centralization the peril of the political administrator and the peril of the military leviathan, respectively. Though, strictly speaking, they are not only dangers, but also necessities for self-determination, understood as democratic control. For self-determination to be effectively exercised, the scope of political authority must be greater than the forces it seeks to control. However, this, in turn, raises the specter of the immense difficulty, if not impossibility, involved in efforts to transcend the state in the name of direct democracy.

In order to successfully confront the state, as well as the corporations and the propertied classes who the state represents, the movement will tend to end up building a counter-state of its own. And when it does this, the so-called principal-agent problem will rear its ugly head. The agents delegated to represent the will of the people will be faced with the temptation of pursuing their own interests instead. Or the interests of particular factions with whom the political counterelites are themselves organically linked.

\section{FROM THEORY TO PRAXIS IN ROJAVA}

Such are some of the dilemmas, the aporias, of the "libertarian municipalist" or "democratic confederal" project in theory. Let us now turn to analyze how they play themselves out in praxis, in one crucial context, that of the north east of Syria, centered in Rojava, where revolutionary forces directly inspired by the prolific writings and political program of Abdullah Öcalan have become hegemonic, managing to fill a vacuum of power caused by the outbreak of the Syrian civil war.

Öcalan had spent close to 2 decades in exile in Syria, before being forced out in 1998, which triggered a sequence of events, the unfolding of an international conspiracy, culminating in his abduction in Kenya on February 15th, 1999, while en route to South Africa (White, 2000, p.185-186; Gunes, 2012, p.134-135; Miley et al., 2018, p.53). He left behind in Syria a committed core of followers, inspired by his teachings, and organically linked to the broader organizational structure of the Kurdistan Workers' Party (PKK), whose core constituency was concentrated in the Kurdish region of Turkey, and whose paramilitary headquarters was located in the Qandil mountains, in the Kurdish region of Iraq. The PKK, of course, had been engaged in an armed conflict with the Turkish state, dating back to the mid-80's (McDowell, 1996; Jongerden and Akkaya, 2016). From the early 90's, however, Öcalan, who remains the nominal head of the PKK to this day, had repeatedly been calling for an end to the armed conflict and the commencement of peace negotiations (White, 2015; Miley et al., 2018).

After his departure and abduction, the followers of Öcalan in Syria faced a climate of fierce repression by the Baathist authorities (Gunter, 2014, p.41; Allsopp, 2015). Nevertheless, they came to organize themselves, principally, in the Democratic Union Party, or PYD, which was founded in 2003, and which began, on the initiative of the PKK, to clandestinely "establish committees to organize and discuss political developments, teach small-group Kurdish-language courses, administer local justice, and address women's issues" (Knapp et al., 2016, p.84). From 2007 forward, the PYD adopted a program of "democratic autonomy," in parallel with the strategic reorientation and reorganization of the broader movement, and therefore with similar developments in the north of Kurdistan, under Turkish rule, in accordance with Öcalan's recommendations. As a core part of this new program, the PYD committed itself to the creation and construction of a set of peoples' councils, which came into being across the main cities of Rojava. Though, as Allsopp and van Wilgenburg have emphasized, under Baath party rule, these new, alternative structures "gained very little attention and did not challenge the pre-existing sub-state social structures directly" (2019, p.90).

However, amidst the polarization provoked by the outbreak of the so-called Arab Spring, and Syria's subsequent descent into civil war, the PYD managed to manoeuvre successfully. It opted for a "third path," siding neither with the increasingly Islamized and armed opposition, nor with the Baath regime. Against this turbulent backdrop, the PYD's council system proved "sufficient to constitute a vibrant structure parallel to the state without being in direct conflict with it" (Knapp et al., 2016, p.85). And indeed, from March of 2011, "the weakening of central governance structures... provided opportunity to seize greater autonomy, and the PYD began expanding its civil organizations and forming 
armed groups on the local levels" (Allsopp and van Wilgenburg, 2019, p.90).

Gradually, the PYD and its affiliated armed groups began to "assert control, establishing" a series of "armed checkpoints" across the region. At first, the establishment of these armed checkpoints occurred "in parallel to Syrian government security services and structures" (Allsopp and van Wilgenburg, 2019, p.91). Moreover, their establishment stirred up considerable controversy and conflict with rival Kurdish organizations, aligned with the Barzani clan in control of the Kurdish Regional Government in Iraq.

Then, in July of 2012, the regime decided to redeploy, to retreat from the region, and to concentrate its forces instead in the effort to suppress the uprisings across the corridor running from Aleppo through Damascus. There are two different versions of the regime's withdrawal, each relayed by Schmidinger in his rather meticulous journalistic account. According to one version, the PYD issued an ultimatum to the regime, threatening it with the spectre of opening up another front of conflict should it not retreat; according to another, somehow less becoming to the revolutionary credentials of the forces in charge in Rojava, the PYD came to a secret agreement with the regime, among other things, "guarantee[ing] the security of important military installations" in exchange for the regime's departure (2018, p.91; see also Gunter, 2014, p.110-111; and Leezenberg, 2016, p.681). Either way, once "the Syrian government began its withdrawal..., the PYD stepped into the governance void and took over key services and practical administrative duties" (Allsopp and van Wilgenburg, 2019, p.91).

The circumstances in which the revolutionary forces came to power thus differ quite substantially from the scenario of dual power envisioned by Bookchin. For Bookchin foresaw a grassroots movement gaining momentum, growing from the bottom up, progressively raising the consciousness of the citizenry, provoking a conflict with the state. What happened in Rojava, by contrast, was more of a military achievement than anything else, accomplished by cohesive and well-trained armed groups, affiliated with the PYD, who proved able to take advantage of a vacuum of power triggered by a civil war. A civil war, we should add, that it did not provoke, and towards which it did its best to maintain a posture of neutrality.

\section{TOWARDS DIRECT DEMOCRACY?}

An opportunity arose, a revolutionary situation perhaps, in which the state effectively vanished, without much in the way of a direct confrontation. But such are not the conditions for selfdetermination, understood as bottom up democratic control. For the revolutionary citizenry envisioned by Bookchin as the precursor and precondition for the emergence of a situation of dual power was only very incipient, just in gestation, when the revolutionary opportunity provided by state withdrawal presented itself. Consequently, we can say that, in Rojava, the revolutionary situation induced popular mobilization and the consolidation of the popular assemblies or council system, rather than the other way around.
Especially given the initial military basis of the PYD's power, its organization of the popular assemblies has had something of a top down, militarist, and explicitly partisan flavor to it from the outset. In accordance with Mao's dictum, we can conclude, its political power was born from the barrel of a gun, not from the popular demand of a mobilized people, immersed in a directdemocratic culture, possessed of revolutionary consciousness, at least not of the kind that Bookchin had in mind.

It must be mentioned that the hegemony of the PYD is not based on military might alone. Rather, it is based as well on the legacy of activism and mobilization of Syrian Kurds since the 1980 s by the PKK. Empowered by Öcalan's philosophy and guidance, the PYD has taken the "third path" during the Syrian revolution, siding with democratic forces, and thus has avoided being trapped either by the Syrian regime or the Syrian opposition, as both share the same mentality in denying Kurdish rights. In fact, the PYD has strategically interpreted the Syrian revolution correctly and contributed to the formation of selfdefense units with strong support from its base. What the PYD can be blamed for, as we shall see, is its failure to deliver on its promise to empower people in communal democracy, due to its monopolization of decision-making. This is what we have referred to as the peril of the political administrator, which is in turn related to the PYD's organic links with the "military leviathan," in the form of these self-defense units. According to the principles of democratic confederalism, these units are supposed to be subordinate to the power of the communes, but, as again we shall see, they are not. None of this, however, is meant to deny the great and heroic sacrifices the people of North East Syria have made in order to protect themselves against dictatorship and authoritarian states (the Syrian regime and the Turkish state), and against brutal and inhumane Islamist forces.

Even so, as one of our anonymous reviewers pithily put the point: "the problem is not only that [the revolutionary forces' actions] do not conform to what Bookchin once thought. . but rather what the historico-social conditions in Kurdistan enforced." Indeed, many of the people close to the movement in Rojava whom we interviewed spoke about geopolitical and historical obstacles that have played a role in preventing communes from reaching their full potential. They emphasized the war situation, the embargo, the fight against IS, and the instability in northeastern Syria that they face on a daily basis. They also pointed out that the relic of the Syrian nation-state remains ingrained in the mentality of many who are active in the institutions of the administration, who still see the administration as a form of the state.

And yet, revolutionary consciousness there was. Amongst a core of cadres, professional revolutionaries, per chance, people whose lives have been entirely dedicated to the movement, many of whom had experience fighting as guerrillas in the PKK's ongoing war against the Turkish state. It is the existence of this core of cadres that helps account for the military superiority of the PYD-affiliated forces, in comparison to nearly any other fighting force in the region. For they are seasoned fighters, blessed with the courage of their convictions. However, at the same time, their highlydisciplined mentality, and status as a revolutionary vanguard, 
has introduced a certain performative contradiction into their explicit goal of constructing a democratic confederal society. For, as Cihad Hammy has elsewhere argued, the party to which they belong remains "structured around the system of command and obedience" (2018; see also Leezenberg, 2016, p.685).

In a similar vein, Cinar Salih, who is affiliated with the movement's Al Furat Center for Studies, located in Quamishli, would advance the following criticism: "There is a big difference between the party cadre and the thought cadre. Öcalan relies on the thought cadre for the project and not the party cadre. However, it is very difficult to create such cadres. Unfortunately, most of the cadres we have here are party cadres and not thought cadres" (Interview, November 5, 2021).

Likewise, another person whom we interviewed, Ibram Bozan, a journalist from Kobane and self-described Apoci, would contend: "When this project was put into practice, there were some people-cadres-who intentionally turned this project into rigid slogans. By doing so, they caused serious damage to the project and the philosophy of Öcalan. Some did it intentionally, others out of ignorance. Those who did it intentionally want to have more power and elevate themselves to the rank of a higher level. For example, they would say, 'We do not believe in the law because Öcalan criticized the rigidity of the law'. Under this pretext, they make themselves the law, and they act according to their personal whims. They do not act according to laws or measures. They might say, 'I don't like this person, so he should be excluded.' The excluded person could be without a job and have no place in the administration. And there are many real examples like this. Of course, we cannot make a final judgment about whether the project failed or not. It is true that it has been 10 years, but during these years Rojava has always been under war and danger. There have been constant wars during these years: the attack on Kobani, the occupation of Afrin, Serkanya and Tel Albyad, and the war against IS. There have been some changes. For example, the liberation of women. To put a new project into practice, you need a safe environment. In Rojava, there are many external factors that strongly influence it. The war must be stopped so that we can really see how things will go" (Interview, November 7, 2021).

The People's Defence Units, or YPG, were officially established in 2012, alongside the all-women, Women's Protection Units, or YPJ. These organizations quickly grew, and, according to Allsopp and van Wilgenburg, the YPG was soon transformed, under the direction of the veteran PKK commander, Xebat Derik, into something of "a quasi-state security force." By 2017, the YPG's ranks counted approximately 50,000 soldiers. Though it is controversial to admit as much, it would appear that many of the YPG's units have been "commanded by PKK veterans," who thus provide the organization's "'skeletal' structure..., 'fleshed out' by local recruits” (2019, p.65).

The YPG is formally autonomous from the PYD, but it is clearly aligned with the revolution. From the middle of 2014, it would come to be supplemented by Self-Defence Units, created for the purpose of compulsory military service. From 2015, the YPG would form the backbone of a military alliance with other ethnically-composed militias, including Arab and Syriac forces, known as the Syrian Democratic Forces, or SDF, which came together in the course of the fight against ISIS, and which, in that struggle, forged a close working relationship with the United States military, despite vehement objections from the U.S.'s NATO ally, Turkey.

It is the achievements of the YPG and YPJ, their effectiveness in the war against ISIS, for which the revolutionary forces in power in Rojava have garnered most accolades and attention. The democratic confederal model of society for which they claim to be fighting, however, has received significantly less attention.

How are the popular assemblies or local councils functioning? Allsopp and van Wilgenburg managed to conduct a survey with some 180 randomly-selected individuals from the cantons of Jazira and Kobani, in an attempt to gauge the attitudes of the local citizenry about their new, direct-democratic institutions. What they found is somewhat disturbing, and certainly highlights some of the challenges for constructing a democratic-confederal society that truly lives up to the goal of "open[ing] political space for all social strata and allow[ing] diverse political groups to express themselves" (Öcalan, 2011b, p.26).

For starters, Allsopp and van Wilgenburg found that there was a relatively high level of non-participation in the popular assemblies. Indeed, fully one third of their interviewees volunteered, without even being asked, the information that they did not participate in these assemblies. "Participation in the commune system was limited," Allsopp and van Wilgenburg conclude (2019, p.144). Of particular interest is their contention that this limitation in terms of the rate of popular participation has a lot to do with the perceived "ideologization of the system," that is, its "partisan appearance" (2019, p.144). To this end, they contend that the "communes were widely reported to be dominated by PYD sympathizers (hevals), if not by members themselves, and the topics discussed and decisions made reflected the interests of the PYD-led administration" (2019, p.145). Moreover, they continue, there were "many claims that decision-making was limited to those connected to the PYD administration," that "whether or not participants opinions were considered depended on their personal connections," and even that "communal discussions and processes were a façade" (2019, p.145). Even more troubling, they report, "surveys also contained evidence that some people did not feel free to express their opinions if they might differ from PYD doctrine or ideology" (2019, p.145). Overall, and perhaps most damningly, they insist, "[1] ocals reported concerns that decisions were not driven by the processes or products of direct democracy, but rather that they were already made and discussion provided [but] an illusion of consultation" (2019, p.147).

In sum, what Allsopp and van Wilgenburg found was that "the development of the administration after 2012 occurred from the top-down, from the PYD, and it was an attempt to stimulate and realize a grass-roots revolution; " but that this "top-down, PYDled implementation... [has] led to distrust of its institutions by much of the population not politically sympathetic to the PYD and averse to the domination of one political party" (2019, p.147; cf. Colsanti et al., 2018).

Thomas Schmidinger concurs with Allsopp and van Wilgenburg's critical assessment of the functioning of the council system, of its exclusions and limitations in practice. 
He contends that, though, "in theory," the council system is "based on direct democracy," in fact it is "dominated by the supporters of the PYD and the latter's front organizations." Indeed, he continues, somewhat provocatively, by interrogating, "just like other historic council systems such as in the former Soviet Union, the question is who is really in the possession of political power: Is it, in the end, really 'all power to the councils,' or is it, after all, still 'all power to the party', or even to the army, that is, in this case, the YPG?" (2018, p.134).

Schmidinger dismisses as romantic idealization, if not deliberate propaganda, the assessment of "activists close to the PKK/PYD," such as Knapp, Flach, and Ayboga, in whose pioneering account, Revolution in Rojava, had made the claim that the council system amounted to nothing short of "the realization of the political theory of the US eco-anarchist Murray Bookchin and the 'attempt at a unification of the [...] concepts of Democratic Autonomy, Confederalism, and a Democratic Republic on a small scale' (2018, p.134). But at the same time, he also disputes the accounts of "less enthusiastic observers," such as the political scientist Michael Gunter, according to whom "the leadership of the PKK in the Qandil mountains .... are the ones who exercise real control" (2018, p.134).

Like Gunter, Schmidinger does, in fact, insist, that " $\mathrm{t}]$ here are ... indications that the YPG, and, via the YPG, the headquarters of the PKK in Qandil, has the final say in decisive questions." He, furthermore, maintains that " $[t]$ he long-lasting civil war has certainly contributed to a strengthening of the role of the military, that is, the YPG," noting, in this regard, that " $\mathrm{t}]$ he members of the competing militia in the Syrian civil war have always regarded the commanders of the YPG as their serious contact partners, not the representatives of the political structures." Even so, on the other hand, he also insists that "the council system does play an important role in ... small daily administrative decisions and the supply of the population; " that the councils provide important "feedback loops and local organizers; " that they "also provide propaganda for and the dissemination of the social model the PYD is striving for; " and finally, that, [p] articularly with regard to the role of the women in Kurdish society, the councils play an important role in reforming an extremely patriarchal society" (2018, p.135). The last point, about the role of women in the council system, is one about which Allsopp and van Wilgenburg also reported many of their interviewees had mentioned, in a positive vein (see Dirik, 2018; Rasit and Kolokotronis, 2020).

Schmidinger goes on to emphasize that "[o]ne of the biggest problems for the new system remains the lack of support of a large number of the Kurdish parties," though he also adds that "since the establishment of the self-administration in Rojava opposition to the PYD has... eroded" (2018, pp.135-136). He discusses in some detail the contours and content of an always present, sometimes intensifying intra-Kurdish conflict, between the PYD and the forces aligned with Barzani's Kurdish Regional Government in Iraq, before concluding that, over time, "the opposition to the PYD [has become] more fragmented than at the beginning of Rojavan autonomy" (2018, p.137).
Interestingly, Schmidinger diagnoses as well the existence of fissures and factions within the PYD, in particular stressing the ascendance within its ranks of certain opportunistic elements, some who before 2012 had "already been in high positions under the Ba'ath regime," and even a few noteworthy "big businessmen," which was a source of resentment among "many of the old leftists in the party" (2018, p.137). The newfound prominence of these opportunistic elements, Schmidinger notes, "follows a certain logic in the exercise of power [that] always confronts societies in political turmoil with massive challenges" (2018, p.138). Nevertheless, he simultaneously seems to suggest, this phenomenon seemed a source of significant disenchantment among not only long-time party loyalists but also the population more generally.

In relation to the mood among the general population, Schmidinger likewise diagnoses a rather quick and serious cooling off of initial revolutionary enthusiasm, associated especially with the onset of the war with ISIS. He notes that, back in 2013, when he was first doing fieldwork in the region, "a revolutionary atmosphere was prevalent," that though " $\mathrm{t}] \mathrm{he}$ people suffered from supply bottlenecks and uncertainty, [they] still took to the streets every week and bristled with hope and dynamism." However, already by 2014, "not much of this revolutionary atmosphere was still palpable among the ordinary population," indeed, that the initial optimistic mood had been replaced "by the mood typical of a civil war" instead (2018, p.138).

In sum, the overall picture of the functioning of the popular assemblies, at least as portrayed by the likes of Allsopp and van Wilgenburg, and by Schmidinger, is quite far from the more optimistic assessment provided by Knapp, Flach, and Ayboga, who judge " $t$ ] he proliferation of communes in Rojava..., as well as the development of a communal economy" to be "the expressions of an alternative to capitalist modernity, developed slowly but steadily" (2016, p.120).

Our interviews with people close to the movement in Rojava tend to reinforce some of the critical observations made by outsiders about the limits to bottom-up, grass roots democracy in the revolution. For example, in this vein, Ibram Bozan would complain: "The commune only does small bureaucratic tasks and provides people with gas cylinders and bread. It has no real power. The decisions come from above and the commune just implements them" (Interview, November 7, 2021). Similarly, another person whom we interviewed, who asked to be identified only as a citizen from Rojava, would contend: "One of the problems of the commune system is that councils, which should be elected by communes and take their decisions based on communes, are completely separate from communes. People in councils are appointed by the administration and they make decisions, and they don't care about communes. Communes should be the foundational basis of all institutions in the administration. But in reality, communes are limited to mere service functions with no real power as they should be" (Interview, November 3, 2021).

What is the upshot of this analysis from the standpoint of revolutionary theory? David Graeber, who visited the region twice before his untimely demise, diagnosed a dual power 
situation, between, on the one hand, "the democratic selfadministration, which looks very much like a government, replete with ministries, parliament, and higher courts," and, on the other, "the bottom-up structures... where initiative flows entirely from popular assemblies" (2016, p.xvii). In a similar vein, Nazan Üstündag has insisted that "the relationship between the canton government and assemblies" is best conceived "in terms of self-defense," that bottom-up, direct-democratic institutions "will be the means by which localities maintain their autonomy against the canton governments, unmake the latter's claims to state-ness, and eventually appropriate their functions, proving them redundant" (2016, p.203). Such assessments would still seem to exaggerate the extent of autonomous, bottom-up, grassroots democracy at work, and thereby should be criticised for conflating the slogans of the revolution with the real dynamics of power. To put the point perhaps provocatively, though both Graeber and Üstündag are alive to what we referred to above as the peril of the political administrator, they nevertheless both substantially underestimate the peril of the military leviathan, notwithstanding Üstündag's explicit emphasis on the theme of self-defense.

\section{TOWARDS THE DEMOCRATIZATION OF THE ECONOMY?}

Which brings us to the question of the "communal economy." Knapp, Flach, and Ayboga have hailed the birth of nothing less than a new "social economy" in revolutionary Rojava, which they believe operates more or less in accordance with the principles of democratic confederalism as laid out by Öcalan, and that therefore can be "distinguished from both the neoliberalism of capitalist modernity and from Real Socialism's state capitalism" (2016, p.197). This social economy, they contend, "was to be entrusted to the hands of the society, which would implement economic activities in the residential streets, villages, neighborhoods, district, and cantons" (2016, p.198).

They emphasize, in particular, the proliferation of agricultural cooperative ventures initiated by the communes. They point out that about $80 \%$ of the land in Rojava had been nationalised by the Syrian regime, and that after the revolution, this was turned over to the communes. The remaining $20 \%$, they note, remains in the hands of large landholders. This because, they claim, the new revolutionary authorities "spurn the use of force, so no large landholdings have been expropriated" (2016, p.199). Even so, they continue, the diversity of the cooperative economy "blossoms with every passing year," and, they furthermore stress, the revolutionary forces have "set a goal of extending cooperatives to as many sectors of the economy as possible and of making them, in the near future, the dominant economic form" (2016, p.200). To this end, they highlight the creation of several women's cooperatives.

These proliferating cooperatives, in turn, are in principle subjected to the control of the council system. For, they insist, “[i]n Rojava's social economy, needs are determined not by state or capital but by the communes" (2016, p.205). Though they admit that "[o]ther forms of trade and economy also exist in
Rojava," they nevertheless contend that "the social economy model is spreading fast" (2016, p.206). As such, they can conclude, rather hopefully, that since 2012, despite a brutal embargo pushed by Turkey, intended to "starve their social and political model to death," Rojava has nevertheless "been developing, gradually, an exceptional economic form” (2016, p.207, 209).

For their part, Allsopp and van Wilgenburg observe that "economic organization around the communes and development of cooperatives had, in many cases, eased economic pressures and facilitated necessary cooperation over the distribution of scarce resource and services." Even so, they are quick to add, the fulfilment of "wider economic objectives. . . was hindered by the war, dependence on external supplies of goods and services, as well as by political divisions that prevented cooperation." Allsopp and van Wilgenburg interpret the conflict as having "provided the conditions for reorganizing local society and production around the democratic autonomy model." At the same time, however, they emphasize that "inevitable uncertainties about the future were obstacles to achieving the Administration's economic goals and their longevity." To this end, they highlight how "[n]egative effects on salaries, prices, production and population migration, among other factors, increased general hardship and restricted incomes and resources." As a result, they stress the prevalence of "dependence on private enterprise, black and grey market trade and external remittances, to meet basic individual and family needs," all operating "in parallel to organized cooperative economic activity" (2019, p.102).

Allsopp and van Wilgenburg go on to point out that " $[t]$ he budget of the local administrations derived primarily from oil revenues, taxes on fuel and agriculture, and import duties." They stress that the war has had a serious negative effect on levels of production, and that "border closures and restrictions on trade" have had an adverse impact upon "availability and prices on imported goods" (2019, p.103).

In relation to oil, they note that its "production remains limited," and that revenues remain incomparable to pre-war levels, though they also report that "[b]lack market trade with the Assad government, as well as with the KRG," and taxes on oil produced by ISIS, "transiting through YPG held territory," have been widely alleged to have contributed to the Administration's revenue (2019, p.104).

Theirs is a picture of an economy quite devastated by war. They emphasize in particular the fact that "[e]conomic hardship and difficulties in meeting basic needs increased migration of Kurds from Syria to Europe, Turkey, and to the Kurdistan region [of Iraq]," while simultaneously "produc[ing] dependencies on alternative black/grey market trade or remittances from relatives abroad" (2019, p.107).

They do admit that "[i]nitiatives to develop the social economy and cooperatives and to distribute services according to this model, assisted regulating the war economy." Even so, at the same time, they stress that " $[\mathrm{t}]$ he existence of layers of parallel economies... tied northern Syria intrinsically to the Syrian interior and to its neighbours," and that such ties thus 
"undermin[ed] attempts to develop self-sufficiency" (2019, p.109).

Schmidinger goes even further in relativizing the advances towards the so-called "social" or "communal" economy. $\mathrm{He}$ points out that, despite all the bluster about the creation of a new, "alternative" economy, "neither the Kurdish selfadministration nor independent economists are able to give any reliable facts and figures in that regard" (2018, p.120). With respect to the widely-touted example of women's cooperatives, he contends that, "viewed from the economy at large, these cooperatives ... play a relatively unimportant role" (2018, p.121). Nor does he consider the other cooperatives all that important either. To the contrary, he insists that, on the whole, "the new cooperatives hardly represent an 'alternative economy"” at all. Indeed, to this end, he maintains, "Rojava's economy is based on a mixture of war economy, small capitalism, and subsistence production of food within which the cooperatives lead a niche existence instead of representing a new economic system" (2018, p.121).

Like Allsopp and van Wilgenburg, Schmidinger, too, emphasises the importance of the black market economy, labelling "smuggling" in particular an "important economic factor." According to Schmidinger, the closure of the borders has created this "opportunity," turning "smuggling of all sorts of goods into an attractive business," in which, he insists, "both family clans and party and military structures are involved" (2018, p.121). Alongside the smuggling, and "despite all the fighting," he adds, "there is also an intense intra-Syrian trade that, in the case of Rojava, even crosse[d] the areas held by IS" (2018, p.121).

Besides the smugglers and the traders, "informal financiers" constitute another important part of "the new upper class." These financiers both cater to "the desire of refugees to deposit their money safely in Europe" and help facilitate remittances from abroad, which, Schmidinger insists, "form an increasingly important part of the income of the region" (2018, pp.122-123).

Nor are the profits made by the smugglers, traders, and informal financiers reinvested into productive businesses, Schmidinger adds. This because of the high risk of such investments in the context of a civil war in general, but also, more particularly, because "legal security for investments simply doesn't exist” (2018, p.123).

Finally, Schmidinger stresses that "no evaluation of the economic situation can overlook the fact that many items have become luxury goods in the course of recent years..., unaffordable for an increasing number of Rojavans" (2018, p.123). Furthermore, he contends that these "war-related shortages [have been] made worse by the presence in Rojava of more than a half million internally displaced persons (IDPs) from other parts of Syria," a situation rendered all the more complicated by the fact that "[1]arge international NGO's are virtually non-existent” there (2018, p.123).

The rather grave economic situation, as depicted quite soberly by Allsopp and van Wilgenburg, and even more starkly by Schmidinger, certainly sounds a far cry from the seemingly utopian scenario described in more enthusiastic accounts, such as the one provided by Knapp, Flach, and Ayboga.
A most recent contribution, by Azize Aslan, who writes from a perspective clearly close to the movement, albeit in an expressly self-critical vein, tends to confirm some of the more pessimistic observations made by outsiders about the limits to the socialization of the economy in the context of the ongoing war. To this end, she argues that "the necessity of an anticapitalist economy is not sufficiently internalized and valued by the cadres and political leaders, nor by the peoples [of Rojava]" (2021, p.27). More specifically, with respect to the fate of cooperative initiatives, she even goes so far as to conclude that "the common situation of cooperatives in Rojava is, to a certain degree, one of collapse and distancing from the perspective of the social economy" (2021, p.325). She, furthermore, quotes the head of the Commerce Committee, who frankly admits that "[t]his is a war economy" (2021, p.255). Along such lines, he explained to her, in no uncertain terms, the centrality of the oil trade in relation to the administrative budget. In his words: "We are a society that is at war, we don't have other income besides oil. Without oil, we cannot pay salaries, we cannot maintain the YPG, we cannot buy weapons. Nor can we give this up just because it is not ecological, simply because the matter is more vital than that, it is a matter of life and death for us" (2021, p.241).

And indeed, in our own interviews with people associated with the movement in Rojava, we, too, have come across a good deal of pessimism, as well as discontent, about the limits to the democratization of the economy. For instance, one member of the Kurdish Committee of Jineology articulated the following criticism: "The cooperative economy should be the basis for our project. But even the existing cooperatives were monopolized by people working in the economic field and close to the administration. For example, in Şehba, to support the people, the administration gave financial credits to people to build economic projects. However, only people who were close to the administration received these financial credits, but not the poor people. This is a big problem. Many people have complained about this" (Interview, November 11, 2021). She would, furthermore, go on to make an explicit connection between the failure to build a just economy with the failure to build an ecological society. In her words: "In Öcalan's view, building an ecological society means creating a just economy. Such an economy should not harm the environment. This is the perspective of jineology, which emphasizes that all aspects of life should not be separated. They are interconnected, influence each other and should not harm each other. Politics should serve economics, economics should serve ecology, ecology should serve humanity, and demography should be ecological. Jineology analyzes this very well. Therefore, for Öcalan, the economic projects should be ecological. In fact, one of the main pillars of the 'democratic nation' is ecology. Unfortunately, all the economic projects we have harm ecology. For example, digging wells to obtain water is harmful to ecology. People dig wells without any restriction. This shows that there is a lack of awareness. The economic projects that have been carried out and proposed do not serve our project. They contradict our project. The economic projects that are made here are the same as those of the state" (Interview, November 11, 2021). 


\section{TOWARDS ECOLOGICAL SUSTAINABILITY?}

Given the difficulties encountered in the efforts to overcome hierarchy in all its forms, including the obstacles to the construction of well-functioning, bottom-up, truly popular assemblies, as well as the very limited advances towards a thoroughgoing democratization of economic life, due especially but not only to the context of all-out war, it should come as no surprise that the concrete steps taken towards the realization of ecological sustainability, despite the discursive emphasis on it, have been few and far between.

Though such steps are not non-existent. Knapp, Flach, and Ayboga document in their book an emphasis on the part of the revolutionary authorities to pursue both crop diversification and the use of organic waste as fertilizer, in particular. The Internationalist Commune of Rojava further documents some specific efforts in these regards, and also makes mention of a few important initiatives geared towards water preservation and ecological waste disposal, in the chapter on "Ecological Challenges" in its book, Make Rojava Green Again (2018). But as the title of its chapter, which echoes the same title of a chapter in Knapp, Flach, and Aboyga's otherwise very optimistic book, definitely suggests, when it comes to the ultimate goal and pillar of ecological sustainability, even those closest to the revolutionary forces are willing to admit that, much more than their achievements, what needs to be stressed is the set of immense challenges that they face (see also Hunt, 2019).

Such challenges are not to be underestimated, even if the struggle to overcome all social, political, and economic hierarchies were much further advanced. For indeed, as Stephen Hunt has observed, the transition to ecological sustainability would require "a rapid break with the global fossil-fuel based economy," a task as urgent as it is almost impossible to even imagine against the backdrop of military attacks and economic embargoes (in Hunt, 2021, p.xiv).

Moreover, as Hoffman and Matin (2021) have perspicaciously pointed out, the region's "reliance on oil and its revenues, whether pragmatically or under fiscal duress, fundamentally contradicts the central tenets of Bookchin's 'social ecology' and the cooperative, organic agriculture" upon which it is supposed to be founded. They mention, rightly, in this regard, that Bookchin in fact "single[d] out hydrocarbons not only as a source of environmental, but also of social decay."

The U.S. military presence in the region, of course, has a lot to do with the oil infrastructure (Aslan, 2021, p.242). It is, arguably, the collaboration with the Americans that has heretofore hindered an all-out invasion by Turkish forces to put an end to the revolutionary experiment in Rojava once and for all. Though, it must be noted, such collaboration ultimately proved ineffective at halting the invasion and subsequent ethnic cleansing of the region's western-most canton, Afrin, in 2018, or the further incursion into the north-east of Syria by Turkish forces the following year. Even so, to the extent that the continuing existence of the revolution in Rojava depends upon collaboration with the world's main imperialist power, and NATO ally of Turkey, a break with the global fossil-fuel based economy seems especially hard to fathom. Nor, for that matter, does it seem at all likely that, even in the optimal post-conflict scenario, with the region's eventual incorporation into a democratized and federalized Syrian republic, would there be propitious circumstances for making such a break, either. So there is that major problem or dilemma, one that we cannot afford to forget, or to minimize, from the perspective of social ecology.

Then there is the other crucial issue of the scarce resource of water, upon which the decentralised, ecological forms of agriculture, promoted by the revolutionary authorities and pursued by cooperative ventures accountable to the communes, necessarily depend. Hoffman and Matin (2021) are again perspicacious in making mention of the fact that "under the specific conditions of Northern Syria, this also includes water infrastructure built by the Syrian Arab Republic, which, in turn, is dependent on the upstream control of the Euphrates River by Turkey." A serious vulnerability, to say the least. And one which has been significantly exacerbated "due to the actions of Turkey and its proxies following their military occupation of border areas in 2019," a point to which Nick Hildyard (2021) has recently sought to draw attention. To be specific, Hildyard has lamented how "[s]ince...Turkish-backed militia seized control of the Allouk water station, located near the town of Ras al-Ain (Serekaniye), supplies of water to North East Syria have been repeatedly interrupted by the Turkish authorities." This on top of the fact that, as Hildyard goes on to emphasize, "[b]ecause of dam-building and irrigation schemes in Turkey, the downstream flow of the [Euphrates] river has been reduced by $40-45$ per cent since the early 1970 s, with Turkey deliberately using its storage capacity to exert pressure on its riverine neighbours, particularly in times of conflict."

As such, it turns out that the autonomy to pursue ecologicallysustainable forms of agriculture comes up against two serious geopolitical obstacles, both related to the implacable hostility of Turkey: the first, associated with the region's almost inevitable insertion into the global fossil-fuel based economy; and the second, associated with the region's particular vulnerability and dependency in accessing water. In sum, the relative abundance of one resource, oil, and the relative scarcity of another, water, would both seem to inextricably tie the fate of the revolutionary experiment in Rojava to the broader geopolitical context and dynamics in which it is inevitably embroiled.

And again, in our interviews with people in Rojava close to the movement, we came across very harsh, indeed sobering, assessments of the limits to the ecological initiatives undertaken by the revolutionary forces there. In this vein, one of the founding members of the Greentree Initiative, Ziwar Şêxo, would offer the following criticism: "On the ecological level, selfadministration has remained only a theory. They only have talked about ecology, which is one aspect of the project, in a propagandistic way. However, in practice, the Commission of Ecology is tied to the municipality, which put their efforts on service matters, like cleaning rubbish, paving streets, etc. So the Ecology Office in the municipality is just a form without function. That also applies to the Ecology Administrative Board in Jazira, which is also very weak. Since 2020, many people severely 
criticized them... As far as I know, there are no economic projects based on ecological measures" (Interview, November $8,2021)$.

\section{CONCLUSION}

What lessons can we draw from the above analysis of the experience of Rojava for the paradigm of social ecology? Let us conclude by briefly mentioning three. A first lesson has to do with the conditions in which the "dual power" scenario was overcome, and consequently, how the revolutionary forces managed to establish their hegemony across the north-east of Syria. The retreat of the Syrian state, in the context of a civil war, created the revolutionary situation. The efficacy of the armed forces affiliated with the Öcalan-inspired Kurdish Freedom Movement is what secured the revolutionary outcome of that conjuncture. But these circumstances of state retreat and paramilitary seizure of control have not proven conducive to the consolidation of bottom-up, direct-democratic control. Rather, they have lent something of a top-down, militaristic and partisan flavor to the construction and consolidation of the popular assemblies.

A second lesson has to do with the difficulties of advancing towards the democratization of economic life in the context of a civil war. The proliferation of cooperative ventures, accountable to the communes, seems to have been somewhat dwarfed by the revolutionary authorities' reliance upon oil revenues, as well as by the hardships and "opportunities" presented by border closures and a war economy, which in turn has led to a certain prevalence of smuggling, trade, and informal finance. Rather than the black market constituting a niche within the progressive transformation towards a social economy, the reality would

\section{REFERENCES}

Akkaya, H., and Jongerden, J. (2012). Reassembling the Political: The PKK and the Project of Radical Democracy. Eur. J. Turkish Stud. Soc. Sci. Contemp. Turkey 14. doi:10.4000/ejts.4615

Allsopp, H. (2015). The Kurds of Syria. London: I.B. Taurus.

Allsopp, H., and van Wilgenburg, W. (2019). The Kurds of Northern Syria. Governance, Diversity, and Conflicts. London: I.B. Taurus.

Aslan, A. (2021). Economía anticapitalista en Rojava. Las contradicciones de la revolución en la lucha kurda. Guadalajara, México: Cátedra Interinstitucional Universidad de Guadalajara-CIESAS-Jorge Alonso.

Biehl, J. (1998). The Politics of Social EcologyLibertarian Municipalism. Montreal: Black Rose Books.

Bookchin, M. (1992). "Urbanization without Cities," in The Rise and Decline of Citizenship. Montreal: Black Rose Books.

Bookchin, M. (2005). The Ecology of Freedom. The Emergence and Dissolution of Hierarchy. Oakland, CA: AK Press.

Bookchin, M. (2015a). "The Communalist Project," in The Next Revolution. Popular Assemblies and the Promise of Direct Democracy. Editors D. Bookchin and B. Taylor (London: Verso), 1-30.

Bookchin, M. (2015b). "The Ecological Crisis and the Need to Remake Society," in The Next Revolution. Popular Assemblies and the Promise of Direct Democracy. Editors D. Bookchin and B. Taylor (London: Verso), 31-41. appear to be the other way around. The transition towards democratization, we can conclude, is very much hindered by the introduction of generalized scarcity that goes along with war.

A third lesson has to do with how the autonomy to pursue ecological sustainability can be undermined by a hostile geopolitical context. On the one hand, the addiction to oil proves particularly hard to kick in a context in which, not only must a war be financed, but also, the very survival of the revolutionary experiment ends up depending on collaboration with the world's foremost imperialist power. On the other hand, access to the crucial but scarce resource of water, upon which decentralised, ecological forms of agriculture necessarily depend, has been repeatedly and increasingly threatened by a hostile Turkish state, in control of water flows upstream along the Euphrates. Which ultimately goes to show the grain of truth in the old maxim that, in the long run, for a revolution to survive, it is imperative that it spread. But this point, in turn, obliges us to raise the difficult question: could it spread without war?

\section{DATA AVAILABILITY STATEMENT}

The original contributions presented in the study are included in the article/supplementary material, further inquiries can be directed to the corresponding author.

\section{AUTHOR CONTRIBUTIONS}

The co-authors discussed the ideas presented in the paper at length and wrote the paper together. TM was responsible for the first draft, while $\mathrm{CH}$ conducted several interviews with local informants in Kurdish and Arabic.

Colsanti, N., Frondizi, R., and Liddle, J. (2018). Grassroots Democracy and Local Government in Northern Syria: The Case of Democratic Confederalism. Local Government Stud. 44 (6), 807-825.

Dirik, D. (2018). “Overcoming the Nation-State: Women's Autonomy and Radical Democracy in Kurdistan," in Gendering Nationalism. Editor J. Mulholland (LondonCham: Palgrave Macmillan), 145-163. doi:10.1007/978-3-31976699-7_8

Fischer, F. (2017). Climate Crisis and the Democratic ProspectParticipatory Governance in Sustainable Communities. Oxford: Oxford University Press.

Gerber, D., and Brincat, S. (2021). When Öcalan Met Bookchin: The Kurdish Freedom Movement and the Political Theory of Democratic Confederalism. Geopolitics 26 (4), 973-997. doi:10.1080/14650045.2018.1508016

Graeber, D. (2016). "Foreword," in Revolution in Rojava: Democratic Autonomy and Women's Liberation in Syrian Kurdistan. Knapp et al. (London: Pluto Press). xii-xxii.

Gunes, C. (2012). The Kurdish National Movement in Turkey. From Protest to Resistance. London: Routledge.

Guneser, H. (2021). The Art of Freedom. A Brief History of the Kurdish Liberation Struggle. Oakland, CA: PM Press.

Gunter, M. (2014). Out of Nowhere. The Kurds of Syria in Peace and War. London: Hurst and Company.

Hammy, C. (2021). "Social Ecology in Öcalan's Thinking," in Ecological Solidarity and the Kurdish Freedom Movement. Editor S. Hunt (London: Lexington Books), 25-40. 
Hammy, C. (2018). The First Commune in Kobane: Construction and Challenges. Open Democracy. Sept. $3^{\text {rd }}$. Accessible on-line at: https://www.opendemocracy.net/en/ north-africa-west-asia/first-commune-in-kobane-construction-and-challenges/.

Hildyard, N. (2021). Humanitarian Crisis in North and East Syria. Lett. UK Foreign Secretary. Nov. 6.

Hoffmann, C., and Matin, K. (2021). Beyond Anarchy and Capital? the Geopolitics of the Rojava Revolution in Syria. Geopolitics 26 (4), 967-972. doi:10.1080/ 14650045.2021.1924944

Hunt, S. E. (2019). Prospects for Kurdish Ecology Initiatives in Syria and Turkey: Democratic Confederalism and Social Ecology. Capitalism Nat. Socialism 30 (3), 7-26. doi:10.1080/10455752.2017.1413120

Internationalist Commune of Rojava (2018). Make Rojava Green Again. London: Dog Section Press.

Jongerden, J., and Akkaya, A. (2016). "Kurds and the PKK," in The Wiley Blackwell Encyclopedia of Race, Ethnicity, and Nationalism. Editor J. Stone (London: Routledge), 1-5.

Knapp, M., Anja, F., and Ercan, A. (2016). Revolution in Rojava: Democratic Autonomy and Women's Liberation in Syrian Kurdistan. London: Pluto Press.

Knapp, M., and Jongerden, J. (2014). Communal Democracy: The Social Contract and Confederalism in Rojava. Comp. Islamic Stud. 10 (1), 87-109., No.

Leezenberg, M. (2016). The Ambiguities of Democratic Autonomy: The Kurdish Movement in Turkey and Rojava. Southeast Eur. Black Sea Stud. 16 (4), 671-690. doi:10.1080/14683857.2016.1246529

McDowall, D. (1996). A Modern History of the Kurds. London: I.B. Tauris.

Miley, T., Yildiz, G., and Hammy, C. (2018). "The Turkish-Kurdish Conflict in Historical Context," in Your Freedom and Mine: Abdulah Öcalan and the Kurdish Question in Erdogan's Turkey. Editors T. Miley and F. Venturini (Montreal: Black Rose Books).

Öcalan, A. (2007). Prison Writings. The Roots of Civilisation. London: Pluto Press. Öcalan, A. (2010). Jenseits von Staat, Macht und Gewalt. Neus: Mesopotamien Verlag.

Öcalan, A. (2011a). Prison Writings. The PKK and the Kurdish Question In the $21^{\text {st }}$ Century. London: Transmedia Publishing Ltd.

Öcalan, A. (2011b). Democratic Confederalism. Cologne: International Initiative. Öcalan, A. (2016a). Democratic Nation. Cologne: International Initiative.

Öcalan, A. (2016b). "The Civilizational Crisis in the Middle East and the Democratic Civilization Solution," in Arabic Version: Civilization and the Convening of the Democratic Democracy in the Middle East. Third Edition (Qandil Mountains: Azadi Publications).
Öcalan, A. (2017). “The Manifesto of the Kurdistan Revolution," in Arabic Version: The Kurdish Case and the Dissolution of the Democrats (Qandil Mountains: Azadi Publications).

Öcalan, A. (2015). "Manifesto for a Democratic Civilization," in Volume 1. Civilization: The Age of Masked Gods and Disguised Kings (Porsgrunn: New Compass Press).

Öcalan, A. (2020). The Sociology of Freedom. Oakland, CA: PM Press.

Rasit, H., and Kolokotronis, A. (2020). Decentralist Vanguards: Women's Autonomous Power and Left Convergence in Rojava. Globalizations 17 (5), 869-883. doi:10.1080/14747731.2020.1722498

Schmidinger, T. (2018). Rojava: Revolution, War, and the Future of Syria's Kurds. London: Pluto Press.

S. Hunt (Editor) (2021). Ecological Solidarity and the Kurdish Freedom Movement (London: Lexington Books).

Üstündag, N. (2016). Self-Defense as a Revolutionary Practice in Rojava, or How to Unmake the State. South Atlantic Q. 115 (1), 197-210., No.

White, P. (2000). "Primitive Rebels or Revolutionary Modernizers? The Kurdish National Movement in Turkey. London: Zed Books.

White, P. (2015). The PKK. Coming Down from the Mountains. London: Zed Books.

Conflict of Interest: The authors declare that the research was conducted in the absence of any commercial or financial relationships that could be construed as a potential conflict of interest.

Publisher's Note: All claims expressed in this article are solely those of the authors and do not necessarily represent those of their affiliated organizations, or those of the publisher, the editors and the reviewers. Any product that may be evaluated in this article, or claim that may be made by its manufacturer, is not guaranteed or endorsed by the publisher.

Copyright (C) 2022 Hammy and Miley. This is an open-access article distributed under the terms of the Creative Commons Attribution License (CC BY). The use, distribution or reproduction in other forums is permitted, provided the original author(s) and the copyright owner(s) are credited and that the original publication in this journal is cited, in accordance with accepted academic practice. No use, distribution or reproduction is permitted which does not comply with these terms. 